\title{
PERBANDINGAN MODEL REGRESI KEGAGALAN PROPORSIONAL DARI COX MENGGUNAKAN METODE EFRON DAN EXACT
}

\author{
Asri Lutfia Silmi ${ }^{1 *}$, Sudarno ${ }^{2}$, Puspita Kartikasari ${ }^{3}$ \\ 1,2,3 Departemen Statistika, Fakultas Sains dan Matematika, Universitas Diponegoro \\ *e-mail asriltfslm@gmail.com
}

\begin{abstract}
Cox proportional hazard regression analysis is one of statis tical methods that is often used in survival analysis to determine the effect of independent v ariables on the dependent variable in the formof survival time. Survival time starts from the beginning of the study until the event occurs or has reached the end of the study. The Cox proportional hazard regression model does not require information about the distribution that underlies the survival time but there is an ass umption of proportional hazard that must be met. The purpose of this study is to determine the factors that influence the survival time of coronary heart disease. Ties are often found in survival data, including the survival data used in this study. Ties is an event when there are two or more individuals who experience a failure at the same time or have the same survival time value. The Efron and Exact method approach is used to overcome the presence of ties that can cause problems in the estimation of parameters associated with determining the members of the risk set. The results showed that the variables of diabetes mellitus, family history, and platelets significantly affected the survival time of CHD patients for both methods. The best model obtained is the Exact method because it has smaller AIC value of 383,153 compared to the AIC value of the Efron method of 393,207.
\end{abstract}

Keywords: Cox Proportional Hazard, Efron method, Exact method, Coronary heart disease

\section{PENDAHULUAN}

Menurut Collet (2003) analisis ketahanan hidup merupakan analisis yang digunakan untuk menjelaskan data berupa waktu, mulai dari waktu awal hingga terjadinya peristiwa atau waktu akhir. Terdapat beberapa metode yang digunakan untuk menganalisis data tahan hidup. Salah satunya yaitu metode regresi ketahanan hidup yang digunakan untuk mencari hubungan antara variabel independen terhadap waktu ketahanan hidup sebagai variabel dependennya. Model regresi yang sering digunakan adalah model semiparamterik, salah satunya yaitu regresi kegagalan proporsional dari Cox. Hal ini dikarenakan model regresi tesebut tidak memerlukan informasi tentang distribusi yang mendasari waktu ketahanan (Lee dan Wang, 2003). Dalam data waktu ketahanan hidup seringkali ditemukan adanya kejadian bersama. Kejadian bersama adalah keadaan ketika terdapat dua individu atau lebih yang mengalami kejadiaan pada waktu yang bersamaan atau memilki waktu ketahanan hidup yang sama. Peneliti sering menghindari adanya data yang memiliki kejadian bersama karena dapat mengakibatkan permasalahan dalam membentuk partial likelihoodnya yaitu saat menentukan anggota dari himpunan risikonya.

Pada penelitian ini digunakan model kegagalan proporsional dari Cox untuk mencari pengaruh variabel independen terhadap waktu ketahanan hidup sebagai variabel dependennya. Dalam mengatasi adanya data kejadian bersama digunakan dua pendekatan yaitu dengan pendekatan metode Efron dan Exact. Data yang digunakan merupakan studi kasus penderita penyakit jantung koroner di RSUP Dr. Kariadi Kota Semarang. Penyakit Jantung Koroner (PJK) adalah gangguan fungsi jantung akibat otot jantung kekurangan darah karena adanya penyempitan pembuluh darah koroner. Secara klinis, ditandai dengan nyeri dada atau terasa tidak nyaman di dada ketika sedang mendaki ataupun berjalan terburuburu pada saat berjalan di jalan datar atau berjalan jauh (Kementrian Kesehatan RI,2013).

\section{TINJAUAN PUSTAKA}

2.1. Analis is Ketahanan Hidup 
Kleinbaum dan Klein (2012) menyatakan bahwa analisis ketahanan hidup merupakan prosedur statistika yang digunakan untuk menggambarkan analisis data yang berhubungan dengan waktu, dari diketahui waktu awal(time origin) penelitian yang sudah ditentukan, sampai waktu adanya suatu kejadian (event) atau waktu akhir penelitian (end point). Waktu yang dimaksud dapat dinyatakan dalam tahun, bulan, minggu, atau hari. Sedangkan kejadian dapat berupa kejadian meninggal, sakit, sakit yang terulang, respon dari suatu percobaan, atau peristiwa lain yang dipilih sesuai dengan kepentingan peneliti.

Menurut Lee dan Wang (2003), data waktu pada analisis survival digambarkan atau ditandai dengan tiga fungsi, yaitu fungsi ketahanan hidup (survival function), fungsi kepadatan peluang (density function), dan fungsi kegagalan (hazard function).

\subsubsection{Fungsi Ketahanan Hidup (Survival Function)}

Menurut Lee dan Wang (2003), variabel random yang menyatakan waktu ketahanan hidup sebuah objek disimbolkan dengan $\mathrm{T}$ dan fungsi ketahanan hidupnya dinyatakan dengan $S(t)$ yang menunjukkan probabilitas suatu individu bertahan hidup lebih dari waktu $t$, dengan $t>0$. Maka $S(t)$ dapat didefinisikan sebagai berikut :

$$
\begin{aligned}
S(t) & =P(\text { individu bertahan lebih dari waktu } t) \\
& =P(T>t) \\
& =1-P(\text { individu gagal sebelum waktu } t) \\
& =1-P(T \leq t)
\end{aligned}
$$

\subsubsection{Fungsi Kepadatan Peluang (Density Function)}

Fungsi ini dinotasikan dengan $\mathrm{f}(\mathrm{t})$ dan didefinisikan sebagai probabilitas suatu individu gagal pada interval waktu $\mathrm{t}$ sampai $\mathrm{t}+\Delta t$ atau peluang kegagalan dalam interval per satuan waktu. Fungsi kepadatan peluang dinyatakan dengan

$$
\begin{aligned}
f(t) & =\lim _{\Delta t \rightarrow 0}\left[\frac{P \text { (individu gagal pada interval }(t, t+\Delta t)}{\Delta t}\right] \\
& =\lim _{\Delta t \rightarrow 0}\left[\frac{P(t<T<t+\Delta t)}{\Delta t}\right]
\end{aligned}
$$

\subsubsection{Fungsi Kegagalan (Hazard Function)}

Fungsi ini dinotasikan dengan $h(t)$ dan didefinisikan sebagai tingkat kegagalan bersyarat yaitu probabilitas suatu individu mengalami kejadian dalam interval waktu $t$ sampai $t+\Delta t$, jika diketahui bahwa individu tersebut telah bertahan hingga waktu $t$. Misalkan $T$ variabel random tidak negatif pada interval $[0, \infty]$, yang menunjukkan waktu individu sampai mengalami kejadian pada suatu populasi.

$$
\begin{aligned}
h(t) & =\lim _{\Delta t \rightarrow 0} \frac{p\left[\begin{array}{c}
\text { seorang individu gagal pada interval waktu }(t, t+\Delta t) \\
\text { jika diketahui individu tersebut telah bertahan hingga } t
\end{array}\right]}{\Delta t} \\
& =\lim _{\Delta t \rightarrow 0} \frac{P(t<T<t+\Delta t \mid T>t)}{\Delta t}
\end{aligned}
$$

\subsection{Data Tersensor}

Lee dan Wang (2003) menyatakan bahwa data dikatakan tersensor apabila data tidak dapat diamati secara lengkap karena subjek penelitian hilang atau mengundurkan diri atau sampai akhir penelitian subjek tersebut belum mengalami kejadian tertentu. Ada tiga tipe penyensoran yang sering digunakan dalam eksperimen uji hidup, yaitu sebagai berikut :

1. Sensor Tipe I

Tipe penyensoran ketika semua $n$ objek masuk pada waktu bersamaan dan percobaan akan dilakukan selama waktu $\mathrm{T}$ yang telah ditentukan dan akan berakhir setelah mencapai waktu T. 


\section{Sensor Tipe II}

Tipe penyensoran ketika semua objek yang diteliti $(n)$ masuk pada waktu bersamaan dan pengujian akan dihentikan sampai $r$ dari $n$ individu mengalami kematian.

3. Sensor Tipe III

Tipe penyensoran ketika objek yang diteliti masuk ke dalam percobaan pada waktu yang berbeda selama periode waktu tertentu.

Menurut Kleinbaum Kleinbaum dan Klein (2005) terdapat tiga penyebab terjadinya data tersensor, yaitu :

1. Study ends no event yaitu subjek tidak mengalami kejadian sebelum penelitian berakhir.

2. Lost to follow up yaitu subjek menghilang selama masa pengamatan.

3. Withdraws yaitu subjek ditarik dari penelitian sebelum pengamatan berakhir karena kematian atau alasan lain

\subsection{Regresi Kegagalan Proporsional dari Cox}

Menurut Kleinbaum dan Klein (2005), regresi kegagalan proposional dari Cox adalah model matematika yang populer digunakan untuk menganalisis data ketahanan hidup. Melalui model regresi kegagalan proporsional dari Cox dapat diketahui pengaruh dari variabel bebas terhadap variabel terikat yaitu waktu ketahanan hidup suatu objek terhadap suatu peristiwa tertentu. Persamaan kegagalan proporsional dari Cox dapat dituliskan sebagai berikut :

$$
\begin{aligned}
h(t, \mathbf{X}) & =h_{0}(t) \exp \left(\beta_{1} X_{1}+\beta_{2} X_{2}+\cdots+\beta_{p} X_{p}\right) \\
& =h_{0}(t) \exp \left(\sum_{i=1}^{p} \beta_{i} X_{i}\right)
\end{aligned}
$$

dengan :

$h(t, \mathbf{X})$ : risiko kematian individu pada waktu $t$ dengan karakteristik $X$

$h_{0}(t)$ : fungsi kegagalan dasar

$\beta_{i} \quad$ : parameter dari model regresi, dengan $i=1,2, \ldots, p$

$X_{i} \quad$ : nilai variabel bebas, dengan $i=1,2, \ldots, p$

\subsection{Estimasi Parameter Tanpa Kejadian Bersama}

Regresi pada persamaan kegagalan proporsional dari Cox dapat diketahui dengan menggunakan metode Maximum Partial Likelihood Estimation (MPLE). Pendugaan nilai parameter $\beta$ dengan metode MPLE adalah nilai ketika fungsi partial likelihood maksimum. Secara umum, fungsi partial likelihood dapat dinyatakan sebagai berikut :

$$
L(\boldsymbol{\beta})=\prod_{j=1}^{r} \frac{\exp \left(\boldsymbol{\beta}^{\prime} \boldsymbol{x}_{j}\right)}{\sum_{l \in R\left(t_{(j)}\right)} \exp \left(\boldsymbol{\beta}^{\prime} \boldsymbol{x}_{l}\right)}
$$

dengan :

$\boldsymbol{\beta} \quad$ : vektor koefisien regresi

$\boldsymbol{x}_{j} \quad$ : vektor kovariat (variabel bebas) untuk individu yang mengalami kejadian pada saat $t_{(j)}$

$R\left(t_{(j)}\right)$ : himpunan risiko (risk set), semua individu (subjek) yang belum mendapatkan kejadian pada saat $t_{(j)}$

$\boldsymbol{x}_{\boldsymbol{l}} \quad$ : vektor kovariat (variabel bebas) untuk individu yang masih bertahan dan merupakan elemen dari $R\left(t_{(j)}\right)$

Untuk mempermudah pencarian penduga kemungkinan maksimum $L(\boldsymbol{\beta})$, maka persamaan (5) ditransformasikan ke dalam bentuk $\ln$, sehingga persamaannya menjadi sebagai berikut : 


$$
\begin{aligned}
\ln L(\boldsymbol{\beta}) & =\ln \left[\prod_{j=1}^{r} \frac{\exp \left(\boldsymbol{\beta}^{\prime} \boldsymbol{x}_{j}\right)}{\sum_{l \in R\left(t_{(j)}\right)} \exp \left(\boldsymbol{\beta}^{\prime} \boldsymbol{x}_{l}\right)}\right] \\
& =\sum_{j=1}^{r}\left[\ln \frac{\exp \left(\boldsymbol{\beta}^{\prime} \boldsymbol{x}_{j}\right)}{\sum_{l \in R\left(t_{(j)}\right)} \exp \left(\boldsymbol{\beta}^{\prime} \boldsymbol{x}_{l}\right)}\right] \\
& =\sum_{j=1}^{r}\left[\boldsymbol{\beta}^{\prime} \boldsymbol{x}_{j}-\ln \sum_{l \in R\left(t_{(j)}\right)} \exp \left(\boldsymbol{\beta}^{\prime} \boldsymbol{x}_{l}\right)\right]
\end{aligned}
$$

Nilai penduga $\beta$ dapat diperoleh dengan memaksimumkan fungsi log partial likelihood. Persamaan (6) dapat diturunkan nilainya terhadap $\beta$, maka solusi dari persamaan di atas sebagai berikut :

$$
\frac{\partial \ln L(\beta)}{\partial \beta}=0
$$

Persamaan (7) di atas dapat diselesaikan secara numerik atau secara komputasi dengan bantuan software. Metode yang digunakan dalam memaksimumkan adalah prosedur iterasi Newton-Raphson.

\subsection{Estimasi Parameter Pada Kejadian Bersama}

Dalam analisis ketahanan hidup terkadang ditemukan adanya kejadian bersama atau sering disebut ties. Menurut Collet (2015) kejadian bersama atau ties merupakan kejadian ketika terdapat dua individu atau lebih yang mengalami kejadian gagal pada waktu yang bersamaan atau memiliki nilai waktu tahan hidup yang sama. Model proportional hazard untuk data tahan hidup yang terdapat kejadian bersama dapat menimbulkan permasalahan pada estimasi parameter yang berhubungan dengan penentuan anggota dari himpunan risiko. Terdapat tiga metode yang biasa digunakan untuk mengatasi kejadian bersama dalam analisis survivalyaitu metode Breslow, metode Efron, dan metode Exact. Penelitian ini akan menggunakan dua metode yaitu metode Efron dan metode Exact.

\subsubsection{Metode Efron}

Menurut Xinxin (2011) menyatakan bahwa metode Efron adalah metode yang memilki perhitungan yang lebih sederhana sama halnya dengan metode Breslow, tetapi metode Efron lebih akurat daripada metode Breslow terutama ketika ukuran dari himpunan risikonya diselesaikan dengan pengurangan terhadap rata-rata dari nilai fungsi hazard dari variabel ke-j, karena tidak diketahui variabel mana yang mengalami kejadian terlebih dahulu (Feriana,2011). Berikut adalah fungsi likelihood untuk metode Efron menurut Collet (2003)

$$
L\left(\beta_{\text {efron }}\right)=\prod_{j=1}^{r} \frac{\exp \left(\boldsymbol{\beta}^{\prime} \boldsymbol{s}_{j}\right)}{\prod_{k=1}^{d_{j}}\left[\sum_{l \in R\left(t_{(j)}\right)} \exp \left(\boldsymbol{\beta}^{\prime} \boldsymbol{x}_{l}\right)-\frac{k-1}{d_{j}} \sum_{l \in D(t(j))} \exp \left(\boldsymbol{\beta}^{\prime} \boldsymbol{x}_{l}\right)\right]}
$$

dimana:

$\boldsymbol{s}_{j} \quad$ : vektor jumlah dari $p$ kovariat untuk individu yang mendapat kejadian pada saat $t_{(j)}$

$R\left(t_{(j)}\right)$ : himpunan risiko (risk set), semua individu (subjek) yang belum mendapatkan kejadian pada saat $t_{(j)}$

$\boldsymbol{x}_{\boldsymbol{l}} \quad$ : vektor kovariat (variabel independen) untuk individu yang masih bertahan dan merupakan elemen dari $R\left(t_{(j)}\right)$ 
$D\left(t_{(j)}\right)$ : himpunan semua individu yang mendapat kejadian pada saat $t_{(j)}$

$d_{j} \quad$ : banyaknya kejadian pada saat $t_{(j)}$

\subsubsection{Metode Exact}

Metode ini memiliki tingkat komputasi sangat intensif namun dapat memberikan hasil estimasi yang baik meskipun data kejadian bersama dalam ukuran yang sangat besar. Fungsi likelihood untuk metode Exact dari model Cox proportional hazard adalah sebagai berikut (Imanina. 2018) :

$$
L\left(\beta_{\text {exact }}\right)=\prod_{j=1}^{r} \frac{\exp \left(\boldsymbol{\beta}^{\prime} \boldsymbol{s}_{j}\right)}{\sum_{l \in R\left(t_{(j)} ; d_{j}\right)} \exp \left(\boldsymbol{\beta}^{\prime} \boldsymbol{x}_{l}\right)}
$$

dengan:

$\boldsymbol{s}_{j} \quad$ : vektor jumlah dari $p$ kovariat untuk individu yang mendapat

kejadian pada saat $t_{(j)}$

$R\left(t_{(j)}\right)$ : himpunan risiko (risk set), semua individu (subjek) yang belum mendapatkan kejadian pada saat $t_{(j)}$

$d_{j} \quad$ : banyaknya kejadian pada saat $t_{(j)}$

$\boldsymbol{x}_{\boldsymbol{l}} \quad$ : variabel independen pada individu ke-i dengan himpunan risiko 1

\subsection{Asumsi Kegagalan Proporsional}

Kleinbaum dan Klein (2012) menyebutkan bahwa dalam melakukan pengecekan asumsi kegagalan proporsional dapat dilakukan dengan menggunakan penaksiran Goodness of Fit. Metode penaksiran Goodness of Fit ini menggunakan statistik uji dalam evaluasi asumsi kegagalan proporsional sehingga lebih objektif dibandingkan dengan metode grafis. Statistik uji yang digunakan dalam metode ini adalah schoenfeld residuals dengan langkahlangkah pengujian sebagai berikut :

1. Membangun model kegagalan proporsional dari Cox dan schoenfeld residual untuk masing-masing individu pada setiap variabel bebas.

2. Membuat variabel yang menyatakan peringkat dari waktu ketahanan hidup

3. Menguji korelasi antara variabel schoenfeld residual dengan waktu ketahanan hidup pada langkah ke-2.

Hipotesis :

$H_{0}: \rho=0$

$H_{1}: \rho \neq 0$

Statistik Uji :

$$
r_{\text {hitung }}=\frac{\sum_{j}^{n}\left(R_{i j}-\bar{R}_{i j}\right)-\left(R T_{j}-\overline{R T}_{j}\right)}{\sqrt{\sum_{j}^{n}\left(R_{i j}-\bar{R}_{i j}\right)^{2}} \sqrt{\sum_{j}^{n}\left(R T_{j}-\overline{R T}_{j}\right)^{2}}}
$$

dimana :

$r_{\text {hitung }}$ : koefisien korelasi

$R_{i j} \quad$ :schoenfeld residual untuk masing-masing variabel bebas ke-i dengan $\mathrm{i}=1,2, \ldots, \mathrm{p}$ untuk individu ke-j dengan $\mathrm{j}=1,2, \ldots, \mathrm{n}$

$R T_{j} \quad$ : waktu ketahahan hidup individu ke-j

Kriteria Penolakan

$H_{0}$ ditolak jika $\left|r_{\text {hitung }}\right|>r_{n-2, \frac{\alpha}{2}}$ atau $p$-value $<\alpha$ 


\subsection{Pengujian Parameter}

Menurut Hosmer et al. (2008) untuk menguji signifikansi parameter dapat dilakukan dengan menggunakan uji rasio likelihood dan uji wald. Pengujian signifikansi parameter bertujuan untuk memeriksa apakah variabel independen memiliki pengaruh dalam model.

a. Pengujian Secara Serentak (Uji Rasio Likelihood)

Hipotesis :

$H_{0}: \beta_{1}=\beta_{2}=\cdots=\beta_{p}=0$

$H_{1}$ : minimal ada satu $\beta_{i} \neq 0$, dengan $i=1,2, \ldots, p$

Statistik Uji :

$$
G=-2[\ln L(0)-\ln L(\hat{\beta})]
$$

Kriteria Penolakan :

$H_{0}$ ditolak jika $\mathrm{G} \geq x^{2}{ }_{(\alpha ; d b=p)}$ atau p-value $<\alpha$

b. Pengujian Secara Parsial (Uji Wald)

Hipotesis :

$H_{0}: \beta_{i}=0$

$H_{1}: \beta_{i} \neq 0$, dengan $i=1,2, \ldots, p$

Statistik Uji :

$$
Z^{2}=\left[\frac{\widehat{\beta}_{l}}{S E \widehat{\beta}_{l}}\right]^{2}
$$

dengan $S E \widehat{\beta}_{l}=\sqrt{\operatorname{var} \widehat{\beta}_{l}}$

Kriteria Penolakan :

$H_{0}$ ditolak jika $Z^{2}>x^{2}{ }_{(1 ; \alpha)}$ atau p-value $<\alpha$.

\subsection{Model Terbaik}

Menurut Collet (2005), pemilihan model terbaik dari beberapa model dapat dilakukan berdasarkan nilai Akaike's Information Criterion (AIC) dimana model terbaik adalah model yang memilki nilai AIC terkecil. Rumus menghitung nilai AIC adalah sebagai berikut :

$$
A I C=-2 \ln \hat{L}+2 p
$$

dengan:

$\hat{L} \quad$ : fungsi likelihood

$p \quad$ : banyaknya parameter $\beta$

\subsection{Rasio Kegagalan}

Menurut Kleinbaum dan Klein (2005), rasio kegagalan adalah kegagalan untuk satu kelompok individu dibagi dengan kegagalan untuk kelompok individu yang berbeda. Dua kelompok individu yang dibandingkan dibedakan dengan nilai variabel independen. Rasio kegagalan dapat dinyatakan ke dalam bentuk sebagai berikut :

$$
\widehat{H R}=\frac{\hat{h}\left(t, \mathbf{X}^{*}\right)}{\widehat{h}(t, \mathbf{X})}=\frac{\widehat{h}_{0}(t) e^{\sum_{i=1}^{p} \widehat{\beta}_{i} X_{i}^{*}}}{\widehat{h}_{0}(t) e^{\sum_{i=1}^{p} \widehat{\beta}_{i} X_{i}}}=e^{\sum_{i=1}^{p} \widehat{\beta}_{i}\left(X_{i}^{*}-X_{i}\right)}
$$

\subsection{Normalis asi Z-Score}

Datakontinyu pada variabel bebas memilki satuan yang berbeda. Metode normalisasi dilakukan untuk mengatasi rentang nilai antar variabel bebas yang besar, salah satunya metode normalisasi Z-Score. Menurut Bhandare dan Jain (2014) dalam metode normalisasi $Z$-Score nilai dari masing-masing variabel dinormalisasi berdasarkan rata-rata dan standar deviasi dari variabel. Persamaan untuk normalisasi Z-Score sebagai berikut: 


$$
Z=\frac{x_{i}-\mu}{\sigma}
$$

dengan:

$Z \quad$ : nilai masing-masing variabel yang dinormalisasi

$x_{i} \quad$ : nilai masing-masing variabel awal

$\mu \quad$ : rata-rata dari variabel

$\sigma \quad$ : standar deviasi dari variabel

\subsection{Penyakit Jantung Koroner}

Penyakit Jantung Koroner (PJK) adalah penyakit jantung yang disebabkan penyempitan arteri koroner karena terdapat timbunan plak di dalam arteri koroner. Plak tersebut terbentuk dari lemak, kalsium, dan substansi lainnya yang terdapat di darah. Kondisi saat plak tertimbun di dalam lumen arteri disebut aterosklerosis.

Faktor PJK digolongkan dalam dua kelompok, yaitu faktor risiko yang dapat di modifikasi dan yang tidak dapat di modifikasi. Faktor yang dapat dimodifikasi antara lain stres, diabetes melitus, hipertensi, konsumsi rokok, kolesterol tinggi dan inflamasi. Sedangkan faktor tidak dapat dimodifikasi antara lain jenis kelamin, usia, dan faktor genetis atau riwayat keluarga

\section{METODE PENELITIAN}

\subsection{Jenis dan Sumber Data}

Jenis data yang digunakan pada penelitian ini adalah data sekunder yang merupakan data yang diperoleh peneliti secara tidak langsung dari sumbernya atau melalui media perantara (diperoleh atau dicatat oleh pihak lain). Data sekunder yang digunakan peneliti dalam penelitian adalah data dari rekam medis pasien PJK di RSUP Dr. Kariadi Kota Semarang dari bulan Januari 2019 sampai Desember 2019.

\subsection{Variabel Penelitian}

Variabel yang digunakan dalam penelitian ini terdiri atas lama waktu kekambuhan pasien, status, jenis kelamin $\left(X_{1}\right), \operatorname{umur}\left(X_{2}\right)$, status merokok $\left(X_{3}\right)$, diabetes melitus $\left(X_{4}\right)$, $\operatorname{disiplidemia}\left(X_{5}\right)$, riwayat keluarga $\left(X_{6}\right)$, indeks massa tubuh $\left(X_{7}\right)$, $\operatorname{kadar}$ hemoglobin $\left(X_{8}\right)$, kadar trombosit $\left(X_{9}\right)$, kadar leukosit $\left(X_{10}\right)$, dan kadar ureum dalam darah $\left(X_{11}\right)$.

\subsection{Analis is Data}

Langkah-langkah analisis yang dilakukan dalam penelitian ini adalah sebagai berikut:

1. Melakukan analisis deksriptif.

2. Melakukan standarisasi pada variabel bebas kontinyu menggunakan normalisasi Zscore.

3. Pemodelan regresi kegagalan proporsional dari Cox dengan menggunakan metode Efron dan Exact.

a. Membuat model awal regresi kegagalan proporsional dari Cox.

b. Melakukan uji asumsi kegagalan proporsional menggunakan uji Goodness of Fit.

c. Melakukan uji signifikansi parameter yang terdiri dari uji serentak dan uji parsial.

d. Membentuk model akhir regresi kegagalan proporsional Cox.

4. Membandingkan model regresi kegagalan proporsional dari Cox dengan metode Efron dan Exact dengan melihat nilai AIC masing-masing model. Model terbaik adalah model yang memiliki nilai AIC yang lebih kecil.

5. Melakukan interpretasi model terbaik regresi kegagalan proporsional dari Cox yang telah terbentuk. 


\section{HASIL DAN PEMBAHASAN}

\subsection{Analis is Deskriptif}

Pada penelitian ini, jumlah ukuran sampel yang digunakan sebanyak 138 sampel dengan 46 sampel atau 33,3\% sampel merupakan data tidak tersensor dan 92 sampel atau 66,7\% merupakan data tersensor.

4.2. Pemodelan Regresi Kegagalan Proporsional dari Cox dengan Metode Efron

\subsubsection{Pemodelan Awal Regresi Kegagalan Proporsional dari Cox}

Model regresi kegagalan proporsional dari Cox digunakan untuk mengetahui pengaruh variabel bebas terhadap variabel terikat. Variabel bebas yang digunakan dalam penelitian ini yaitu jenis kelamin $\left(\mathrm{X}_{1}\right)$, usia $\left(\mathrm{X}_{2}\right)$, status merokok $\left(\mathrm{X}_{3}\right)$, diabetes melitus $\left(\mathrm{X}_{4}\right)$, dislipidemia $\left(\mathrm{X}_{5}\right)$, riwayat keluarga $\left(\mathrm{X}_{6}\right)$, indeks massa tubuh $\left(\mathrm{X}_{7}\right)$, hemoglobin $\left(\mathrm{X}_{8}\right)$, trombosit $\left(\mathrm{X}_{9}\right)$, leukosit $\left(\mathrm{X}_{10}\right)$, dan ureum $\left(\mathrm{X}_{11}\right)$. Model awal regresi kegagalan proporsional dari Cox dengan metode Efron sebagai berikut :

$$
\begin{aligned}
h(t, X)=h_{0}(t) & \exp \left(-0,1395 X_{1}-0,25344 X_{2}+0,01544 X_{3(\text { dahulu })}-0,87368 X_{3(\text { masih })}\right. \\
& +1,17483 X_{4(\text { diet })}+1,41108 X_{4 \text { (minum obat oral })}+0,63103 X_{5}+0,84499 X_{6} \\
& \left.+0,01205 X_{7}+0,0844 X_{8}-0,29658 X_{9}-0,68912 X_{10}-0,04231 X_{11}\right)
\end{aligned}
$$

\subsubsection{Pengujian Asumsi Kegagalan Proporsional}

Dalam penelitian ini pengujian asumsi kegagalan proporsional dilakukan secara formal dengan uji Goodness of Fit menggunakan schoenfeld residual.

Tabel 1. Pengujian Asumsi Kegagalan Proporsional Metode Efron

\begin{tabular}{lccc}
\hline \multicolumn{1}{c}{ Variabel } & $r_{\text {hitung }}$ & $P$-value & Keputusan \\
\hline$X_{1}$ & $-0,0630$ & 0,642 & Ho diterima \\
$X_{2}$ & 0,0405 & 0,768 & Ho diterima \\
$X_{3(\text { dahulu })}$ & 0,0457 & 0,744 & Ho diterima \\
$X_{3 \text { (masin) }}$ & 0,1180 & 0,412 & Ho diterima \\
$X_{4 \text { (diet) }}$ & 0,1490 & 0,300 & Ho diterima \\
$X_{4 \text { (minum obat oral })}$ & $-0,00005$ & 1,000 & Ho diterima \\
$X_{5}$ & 0,0564 & 0,708 & Ho diterima \\
$X_{6}$ & 0,1680 & 0,192 & Ho diterima \\
$X_{7}$ & 0,1420 & 0,354 & Ho diterima \\
$X_{8}$ & 0,2180 & 0,187 & Ho diterima \\
$X_{9}$ & $-0,1410$ & 0,245 & Ho diterima \\
$X_{10}$ & 0,1270 & 0,437 & Ho diterima \\
$X_{11}$ & $-0,3110$ & 0,134 & Ho diterima \\
\hline
\end{tabular}

Pada taraf signifikansi $\alpha=0,05$ dapat disimpulkan bahwa antara nilai schoenfeld residual dengan waktu ketahanan hidup tidak ada korelasi, artinya semua variabel yang diduga memilki pengaruh terhadap waktu ketahanan hidup pasien PJK memenuhi asumsi kegagalan proporsional.

\subsubsection{Pengujian Parameter}

Setelah diperoleh model awal kegagalan proporsional dari Cox dengan metode Efron dan asumsi kegagalan proporsional terpenuhi, selanjutnya dilakukan pengujian parameter dari model secara serentak menggunakan uji Rasio Likelihood dan secara parsial menggunakan uji Wald.

\section{a. Pengujian Rasio Likelihood Model Awal}


Dari model awal didapatkan kesimpulan bahwa paling sedikit ada satu variabel bebas dari persamaan yang berpengaruh secara signifikan terhadap waktu survival pasien PJK karena $(\mathrm{G}=41,32)>\left(x_{(0,05 ; 13)}^{2}=22,36\right)$ atau $(p$-value $=8 \mathrm{e}-05)<(\alpha=0,05)$.

b. Pengujian Wald Model Awal

Tabel 2. Uji Wald Model Awal Efron

\begin{tabular}{lcccc}
\hline \multicolumn{1}{c}{ Variabel } & Coef & Se(Coef) & $P$-value & Keputusan \\
\hline$X_{1}$ & $-0,1395$ & 0,45559 & 0,75946 & Ho diterima \\
$X_{2}$ & $-0,25344$ & 0,18321 & 0,16657 & Ho diterima \\
$X_{3 \text { (dahulu) }}$ & 0,01544 & 0,38915 & 0,96835 & Ho diterima \\
$X_{3 \text { (masih) }}$ & $-0,87368$ & 0,84964 & 0,30381 & Ho diterima \\
$X_{4(\text { diet })}$ & 1,17483 & 0,47692 & 0,01376 & Ho ditolak \\
$X_{4 \text { (minum obat oral) })}$ & 1,41108 & 0,36526 & 0,00011 & Ho ditolak \\
$X_{5}$ & 0,63103 & 0,35924 & 0,07899 & Ho diterima \\
$X_{6}$ & 0,84499 & 0,39609 & 0,03290 & Ho ditolak \\
$X_{7}$ & 0,01205 & 0,1766 & 0,94558 & Ho diterima \\
$X_{8}$ & 0,0844 & 0,09302 & 0,36423 & Ho diterima \\
$X_{9}$ & $-0,29658$ & 0,20292 & 0,14386 & Ho diterima \\
$X_{10}$ & $-0,68912$ & 0,48366 & 0,15421 & Ho diterima \\
$X_{11}$ & $-0,04231$ & 0,16972 & 0,80312 & Ho diterima \\
\hline
\end{tabular}

Pada uji Wald variabel bebas yang berpengaruh secara signifikan terhadap model antara lain variabel diabetes melitus $\left(X_{4}\right)$ dan riwayat keluarga $\left(X_{6}\right)$. Karena terdapat variabel bebas yang tidak signifikan terhadap model maka variabel bebas yang tidak signifikan dikeluarkan dari model menggunakan seleksi backward.

Proses dilakukan dengan langkah yang sama hingga diperoleh model akhir dengan semua variabel bebas berpengaruh terhadap model.

\section{c. Pengujian Rasio Likelihood Model Akhir}

Dari model akhir diperoleh kesimpulan bahwa paling sedikit ada satu variabel bebas dari persamaan yang berpengaruh signifikan terhadap waktu ketahanan hidup pasien PJK karena $(\mathrm{G}=31,35)>\left(x_{(0,05 ; 4)}^{2}=9,488\right)$ atau $(p$-value $=3 \mathrm{e}-06)<(\alpha=0,05)$.

\section{d. Pengujian Wald Model Akhir}

Tabel 3. Uji Wald Model Akhir Metode Efron

\begin{tabular}{lcccc}
\hline \multicolumn{1}{c}{ Variabel } & Coef & Se(Coef $)$ & P-value & Keputusan \\
\hline$X_{4(\text { diet })}$ & 1,3629 & 0,4625 & 0,003208 & Ho ditolak \\
$X_{4 \text { (minum obatoral })}$ & 1,4171 & 0,3324 & 0,000020 & Ho ditolak \\
$X_{6}$ & 1,1422 & 0,343 & 0,000867 & Ho ditolak \\
$X_{9}$ & $-0,3793$ & 0,1727 & 0,028057 & Ho ditolak \\
\hline
\end{tabular}

Pada uji Wald variabel bebas yang berpengaruh secara signifikan terhadap model antara lain variabel diabetes melitus $\left(X_{4}\right)$, riwayat keluarga $\left(X_{6}\right)$, dan trombosit $\left(X_{9}\right)$.

Karena seluruh variabel pada model telah signifikan maka diperoleh model akhir regresi kegagalan proporsional dari Cox dengan pendekatan metode Efron yaitu sebagai berikut : $h(t, \mathbf{X})=h_{0}(t) \exp \left(1,3629 X_{4(\text { diet })}+1,4171 X_{4(\text { minum obat oral })}+1,1422 X_{6}-0,3793 X_{9}\right)$

\subsection{Pemodelan Regresi Kegagalan Proporsional dari Cox dengan Metode Exact}

4.3.1. Pemodelan Awal Regresi Kegagalan Proporsional dari Cox

Model awal regresi kegagalan proporsional dari Cox dengan metode Exact sebagai berikut : 


$$
\begin{aligned}
h(t, \mathbf{X})=h_{0}(t) & \exp \left(-0,13735 X_{1}-0,25454 X_{2}+0,01338 X_{3(\text { dahulu })}-0,87811 X_{3(\text { masih })}\right. \\
& +1,18283 X_{4(\text { diet })}+1,41637 X_{4(\text { minumobat oral })}+0,63166 X_{5}+0,85259 X_{6} \\
& \left.+0,01129 X_{7}+0,08455 X_{8}-0,3 X_{9}-0,68945 X_{10}-0,0427 X_{11}\right)
\end{aligned}
$$

\subsubsection{Pengujian Asumsi Kegagalan Proporsional}

Setelah didapatkan model awal dilanjutkan dengan pengujian asumsi kegagalan proporsional dengan uji Goodness of Fit menggunakan schoenfeld residual.

Tabel 4. Pengujian Asumsi Kegagalan Proporsional Metode Exact

\begin{tabular}{lccl}
\hline \multicolumn{1}{c}{ Variabel } & $r_{\text {hitung }}$ & $P$-value & Keputusan \\
\hline$X_{1}$ & $-0,1813$ & 0,180 & Ho diterima \\
$X_{2}$ & $-0,1813$ & 0,475 & Ho diterima \\
$X_{3 \text { (dahulu) }}$ & 0,1458 & 0,297 & Ho diterima \\
$X_{3 \text { (masih) }}$ & 0,2092 & 0,145 & Ho diterima \\
$X_{4 \text { (diet) }}$ & 0,2203 & 0,124 & Ho diterima \\
$X_{4 \text { (minum obatoral) }}$ & $-0,0123$ & 0,935 & Ho diterima \\
$X_{5}$ & $-0,0835$ & 0,579 & Ho diterima \\
$X_{6}$ & 0,1385 & 0,282 & Ho diterima \\
$X_{7}$ & 0,1629 & 0,287 & Ho diterima \\
$X_{8}$ & 0,2384 & 0,149 & Ho diterima \\
$X_{9}$ & $-0,1822$ & 0,132 & Ho diterima \\
$X_{10}$ & 0,1161 & 0,476 & Ho diterima \\
$X_{11}$ & $-0,3339$ & 0,108 & Ho diterima \\
\hline
\end{tabular}

Pada taraf signifikansi $\alpha=0,05$ dapat disimpulkan bahwa antara nilai schoenfeld residual dengan waktu ketahanan hidup tidak ada korelasi, artinya semua variabel yang diduga memilki pengaruh terhadap waktu ketahanan hidup pasien PJK memenuhi asumsi kegagalan proporsional.

\subsubsection{Pengujian Parameter}

Setelah diperoleh model awal kegagalan proporsioanal Cox dengan metode Exact dan asumsi kegagalan proporsional terpenuhi, selanjutnya dilakukan pengujian parameter dari model secara serentak menggunakan uji Rasio Likelihood dan secara parsial menggunakan uji Wald.

\section{a. Pengujian Rasio Like lihood Model Awal}

Dari model awal didapatkan kesimpulan bahwa paling sedikit ada satu variabel bebas dari persamaan yang berpengaruh secara signifikan terhadap waktu survival pasien PJK karena $(\mathrm{G}=41,44)>\left(x^{2}{ }_{(0,05 ; 13)}=22,36\right)$ atau $(p$-value $=8 \mathrm{e}-05)<(\alpha=0,05)$.

\section{b. Pengujian Wald Model Awal}

Tabel 5. Uji Wald Model Awal Metode Exact

\begin{tabular}{lcccc}
\hline \multicolumn{1}{c}{ Variabel } & Coef & $\operatorname{Se}($ Coef $)$ & P-value & Keputusan \\
\hline$X_{1}$ & $-0,13735$ & 0,45681 & 0,76366 & Ho diterima \\
$X_{2}$ & $-0,25454$ & 0,18357 & 0,16557 & Ho diterima \\
$X_{3 \text { (dahulu) }}$ & 0,01338 & 0,39001 & 0,972629 & Ho diterima \\
$X_{3 \text { (masih) }}$ & $-0,87811$ & 0,85174 & 0,302559 & Ho diterima \\
$X_{4 \text { (diet) }}$ & 1,18283 & 0,47834 & 0,013407 & Ho ditolak \\
$X_{4 \text { (minum obatoral) }}$ & 1,41637 & 0,36596 & 0,000109 & Ho ditolak \\
$X_{5}$ & 0,63166 & 0,36009 & 0,079406 & Ho diterima \\
$X_{6}$ & 0,85259 & 0,39777 & 0,032078 & Ho ditolak
\end{tabular}




\begin{tabular}{lcccc}
$X_{7}$ & 0,01129 & 0,17708 & 0,949147 & Ho diterima \\
$X_{8}$ & 0,08455 & 0,09335 & 0,365095 & Ho diterima \\
$X_{9}$ & $-0,3$ & 0,20321 & 0,139856 & Ho diterima \\
$X_{10}$ & $-0,68945$ & 0,48445 & 0,154692 & Ho diterima \\
$X_{11}$ & $-0,0427$ & 0,1703 & 0,802013 & Ho diterima \\
\hline
\end{tabular}

Pada uji Wald variabel bebas yang berpengaruh secara signifikan terhadap model antara lain variabel diabetes melitus $\left(X_{4}\right)$ dan riwayat keluarga $\left(X_{6}\right)$. Karena terdapat variabel bebas yang tidak signifikan terhadap model maka variabel bebas yang tidak signifikan dikeluarkan dari model menggunakan seleksi backward.

Proses dilakukan dengan langkah yang sama hingga diperoleh model akhir dengan semua variabel bebas berpengaruh terhadap model.

\section{c. Pengujian Rasio Like lihood Model Akhir}

Dari model akhir diperoleh kesimpulan bahwa paling sedikit ada satu variabel bebas dari persamaan yang berpengaruh signifikan terhadap waktu survival pasien PJK karena $(\mathrm{G}=$ $31,47)>\left(x_{(0,05 ; 4)}^{2}=9,488\right)$ atau $(p$-value $=2 \mathrm{e}-06)<(\alpha=0,05)$.

\section{d. Pengujian Wald Model Akhir}

Tabel 6. Uji Wald Model Akhir Metode Exact

\begin{tabular}{lcccc}
\hline \multicolumn{1}{c}{ Variabel } & Coef & $\mathrm{Se}($ Coef $)$ & P-value & Keputusan \\
\hline$X_{4(\text { diet })}$ & 1,371 & 0,464 & 0,00313 & Ho ditolak \\
$X_{4 \text { (minum obat oral })}$ & 1,4217 & 0,333 & 0,00002 & Ho ditolak \\
$X_{6}$ & 1,1492 & 0,3444 & 0,00085 & Ho ditolak \\
$X_{9}$ & $-0,3817$ & 0,1731 & 0,02741 & Ho ditolak \\
\hline
\end{tabular}

Pada uji Wald variabel bebas yang berpengaruh secara signifikan terhadap model antara lain variabel diabetes melitus $\left(X_{4}\right)$, riwayat $\operatorname{keluarga}\left(X_{6}\right)$, dan $\operatorname{trombosit}\left(X_{9}\right)$.

Karena seluruh variabel pada model telah signifikan maka diperoleh model akhir regresi kegagalan proporsional dari Cox dengan pendekatan metode Exact yaitu sebagai berikut :

$$
h(t, \mathbf{X})=h_{0}(t) \exp \left(1,371 X_{4(\text { diet })}+1,4217 X_{4 \text { (minum obat oral })}+1,1492 X_{6}-0,3817 X_{9}\right)
$$

\subsection{Perbandingan Model Regresi Kegagalan Proporsional dari Cox dengan Metode Efron dan Exact}

Tabel 7. Perbandingan Nilai AIC Model Efron dan Exact

\begin{tabular}{cc}
\hline Metode & AIC \\
\hline Efron & 393,2069 \\
Exact & 383,1526 \\
\hline
\end{tabular}

Berdasarkan tabel, dapat dilihat bahwa model regresi kegagalan proporsional dari Cox dengan metode Exact memiliki nilai AIC lebih kecil yaitu 383,1526 sehingga dapat disimpulkan bahwa berdasarkan kriteria AIC terkecil maka model terbaik yang diperoleh yaitu model regresi kegagalan proporsional dari Cox menggunakan metoe Exact yang terdiri dari tiga variabel bebas yaitu diabetes melitus $\left(X_{4}\right)$, riwayat keluarga $\left(X_{6}\right)$, dan $\operatorname{trombosit}\left(X_{9}\right)$.

\subsection{Inte rpretasi Model}

Interpretasi rasio kegagalan dari model terbaik yaitu risiko pasien PJK gagal bertahan atau mengalami kekambuhan dari masing-masing variabel bebas yang berpengaruh terhadap model. Pasien PJK dengan diabetes melitus kategori diet dan minum obat oral memiliki risiko gagal bertahan atau mengalami kekambuham lebih besar daripada pasien PJK tanpa diabetes melitus yaitu sebesar 3,939 dan 4,144 kali. Pasien PJK dengan riwayat keluarga 
penderita PJK juga memiliki risiko gagal bertahan atau mengalami kekambuhan lebih besar daripada pasien PJK tanpa riwayat keluarga penderita PJK sebesar 3,1558 kali. Pada variabel kadar trombosit, menurunnya kadar trombosit dalam darah akan menambah risiko yang dimiliki pasien PJK unruk gagal bertahan atau mengalami kekambuhan sebesar 31,73\%.

\section{KESIMPULAN}

Berdasarkan hasil penelitian yang telah dilakukan mengenai regresi kegagalan proporsional dari Cox menggunakan metode Efron dan Exact pada data survival pasien PJK di RSUP Dr. Kariadi Kota Semarang maka dapat diambi kesimpulan sebagai berikut :

1. Pada data yang diterapkan metode pendekatan Efron diketahui variabel yang berpengaruh terhadap waktu ketahanan hidup pasien PJK adalah diabetes melitus $\left(X_{4}\right)$, riwayat keluarga $\left(X_{6}\right)$, dan trombosit $\left(X_{9}\right)$ dengan model akhir kegagalan proporsional dari Cox sebagai berikut :

$h(t, X)=h_{0}(t) \exp \left(1,3629 X_{4(\text { diet })}+1,4171 X_{4 \text { (minum obat oral })}+1,1422 X_{6}-0,3793 X_{9}\right)$

2. Pada data yang diterapkan metode pendekatan Exact diketahui variabel yang berpengaruh terhadap waktu ketahanan hidup pasien PJK adalah diabetes melitus $\left(X_{4}\right)$, riwayat keluarga $\left(X_{6}\right)$, dan trombosit $\left(X_{9}\right)$ dengan model akhir kegagalan proporsional dari Cox sebagai berikut :

$h(t, X)=h_{0}(t) \exp \left(1,371 X_{4(\text { diet })}+1,4217 X_{4 \text { (minum obat oral })}+1,1492 X_{6}-0,3817 X_{9}\right)$

3. Dari kriteria AIC diperoleh model terbaik regresi kegagalan proporsional dari Cox adalah model dengan pendekatan metode Exact dengan nilai AIC sebesar 383,1626 yang lebih kecil dari nilai AIC metode Efron sebesar 393,2069.

4. Interpretasi dari model terbaik untuk masing-masing variabel bebas yaitu untuk pasien PJK dengan diabetes melitus kategori diet dan minum obat oral memiliki risiko mengalami kekambuhan sebesar 3,939 dan 4,144 kali dari pasien PJK tanpa diabetes melitus, pasien PJK dengan riwayat keluarga penderita PJK memiliki risiko mengalami kekambuhan sebesar 3,1558 kali, sedangkan untuk variabel trombosit menurunnya trombosit dalam darah akan menambah risiko pasien PJK mengalami kekambuhan sebesar $31,73 \%$.

\section{DAFTAR PUSTAKA}

Bhandare, S. K. \& Jain, Y. K., 2011. Min Max Normalization Based Data Perturbation Method for Privacy Protection. International Journal of Computer \& communication Technology, 2(8), Hal. 45-50.

Collet, D., 2003. Modelling Survival Data in Medical Research. 2nd ed. New York: CRC Press.

Hosmer, D. W., Lemeshow, S. \& May, S., 2008. Applied Survival Analysis. 2nd ed. New Jersey: Jhon Wiley.

Kementrian Kesehatan Republik Indonesia. 2013. Riset Kesehatan Dasar 2013. Jakarta : Kementrian Kesehatan Republik Indonesia.

Kementrian Kesehatan Republik Indonesia. 2014. Info DATIN Pusat Data dan Informasi Kementrian Kesehatan RI Situasi Kesehatan Jantung . Jakarta

Kleinbaum, D. G. \& Klein, M., 2012. Survival Anyalysis A Self-Learning Text. 3rd ed. New York: Springer.

Lee, E. T. \& Wang, J. W., 2003. Statistical Methods for Survival Data Analysis. Third ed. Oklahoma: John Wiley \& Sons, Inc.,Hoboken, New Jersey.

Sari, D. M., A. \& Purnakarya, I., 2010. Faktor Resiko Kolesterol Total Pasien Penyakit Jantung Koroner di Rumah Sakit Achmad Mochtar Bukittinggi. Jurnal Kesehatan Masyarakat, 4(2), Hal. 77-81. 